\title{
19. QUATERNARY FISH OTOLITHS FROM SITES 587 AND 594, SOUTHWEST PACIFIC, DEEP SEA DRILLING PROJECT, LEG 901
}

\author{
Erlend Martini, Geologisch-Paläontologisches Institut der Universität, Frankfurt am Main \\ and
}

Pieter A. M. Gaemers, Rijksmuseum van Geologie en Mineralogie, Leiden²

\begin{abstract}
Otoliths, predominantly from Lanternfishes (Myctophidae), from two species belonging to the Deepsea Bristlemouths (Gonostomidae), and from one stromatoid species are described from the Quaternary of Sites 587 and 594 in the southwest Pacific. Their occurrences and preservation as well as their present distribution are discussed. Growth layers of some otoliths are described in detail and figured using SEM techniques.
\end{abstract}

\section{INTRODUCTION}

During Leg 90, fish otoliths were found at two out of eight sites (Fig. 1). At Site $587\left(21^{\circ} 11.87^{\prime} \mathrm{S}, 161^{\circ} 19.99^{\prime} \mathrm{E}\right.$, Lord Howe Rise west of New Caledonia, water depth $1101 \mathrm{~m}$ ) approximately 60 otoliths were recovered in the core-catcher samples of Cores 1 to 3, and at Site 594 $\left(45^{\circ} 31.41^{\prime} \mathrm{S}, 174^{\circ} 56.88^{\prime} \mathrm{E}\right.$, Chatham Rise southeast of New Zealand, water depth $1204 \mathrm{~m}$ ) a single otolith was found in Sample 594-3,CC. Most of the otoliths are badly worn, especially in Sample 587-3,CC, but some are fairly well preserved and the genus can be identified.

\section{STRATIGRAPHIC POSITION AND LITHOLOGY}

Samples 587-1,CC, 587-2,CC, and 594-3,CC can be placed in the late Pleistocene to Recent calcareous nannoplankton Zone NN21 (Emiliana huxleyi Zone) and in the planktonic foraminiferal Globorotalia truncatulinoides Zone. Sample 587-3,CC belongs in the Pleistocene calcareous nannoplankton Zone NN19B (upper part of the Pseudoemiliania lacunosa Zone) and in the planktonic foraminiferal Globorotalia truncatulinoides/G. tosaensis overlap Zone used on Leg 90.

Core-catcher Samples 587-1,CC to 587-3,CC consist of very light grey to white foraminifer-bearing nannofossil ooze to foraminifer nannofossil ooze with disrupted pyritized laminae, blebs, and rare burrows. Sample $587-4, \mathrm{CC}$ is a white to bluish white foraminifer-bearing nannofossil ooze. Besides planktonic and benthic foraminifers, the sieved material contains pteropods, echinoid spines, ostracodes, and rare bryozoans. Sample 594-3, CC is a firm, light bluish grey foraminifer- and clay-bearing nannofossil ooze with $\mathrm{H}_{2} \mathrm{~S}$ odor, containing mica and some small mollusk shells.

\section{PRESERVATION AND ABUNDANCE}

In Hole 587 only Cores 1 to 3 (only core-catcher samples investigated) contained fish otoliths in numbers ris-

\footnotetext{
${ }^{1}$ Kennett, J. P., von der Borch, C. C., et al., Init. Repts. DSDP, 90: Washington (U.S, Govt, Printing Office).

2 Addresses: (Martini) Geologisch-Paläontologisches Institut der Universităt, Frankfurt am Main, Federal Republic of Germany; (Gaemers) Rijksmuseum van Geologie en Mineralogie, Leiden, Netherlands.
}

ing with depth (Table 1); no specimens were found in Sample 587-4,CC and below, although the same amount of sediment was checked for each level. The preservation declines rapidly with depth, and otoliths from Sample 587-3,CC are badly corroded, especially on the inner face; this is probably due to the coarser crystal arrangement along the sulcus (Martini, 1974). Accordingly the genus of most cannot be identified with certainty. The single otolith from Sample 594-3,CC from the clay-bearing nannofossil ooze is much better preserved (Plate 1, Figs. 1, 2) than those from Hole 587. It seems possible that in samples from Cores 587-1 to -3, which show generally coarser material and winnowing of the fine fraction, otoliths became concentrated.

\section{DEEP SEA OCCURRENCES OF FISH OTOLITHS}

Fish otoliths are built of aragonite, which is less solution-resistant than calcite (Berger, 1978); accordingly, their occurrence in deep sea sediments is restricted by depth. Only a few papers have mentioned otoliths from deep sea sediments, although under certain conditions they may be found in sufficient numbers. The only detailed account of fish otoliths within the Initial Reports of the Deep Sea Drilling Project is for Leg 25 (Marti$\mathrm{ni}, 1974)$, where Recent to late Pleistocene assemblages were described from present water depths of $2275 \mathrm{~m}$ (Site 242, Mozambique Channel) and $1030 \mathrm{~m}$ (Site 246, Madagascar Ridge) in the Indian Ocean.

Two otoliths were figured by Beckmann (1976) from Site 318; they were recovered during Leg 33 on the Tuamotu Ridge (Sample 318-2-2, 15-17 cm), from Pleistocene sediments placed in calcareous nannoplankton Zone NN19 (Pseudoemiliania lacunosa Zone) at a present water depth of $2641 \mathrm{~m}$. As they were associated with a shallow-water fauna they may represent displaced specimens.

For the Mediterranean Leg 42A, Bizon et al. (1978) noted fish otoliths in several holes but did not describe them in detail. Occurrences were more or less restricted to the Quaternary and included Holes 371 (present water depth $2792 \mathrm{~m}$ ), 372 (present water depth $2699 \mathrm{~m}$ ), 376 (present water depth $2101 \mathrm{~m}$ ), and 378 (present water depth $1835 \mathrm{~m}$ ). Some Pliocene occurrences were noted 


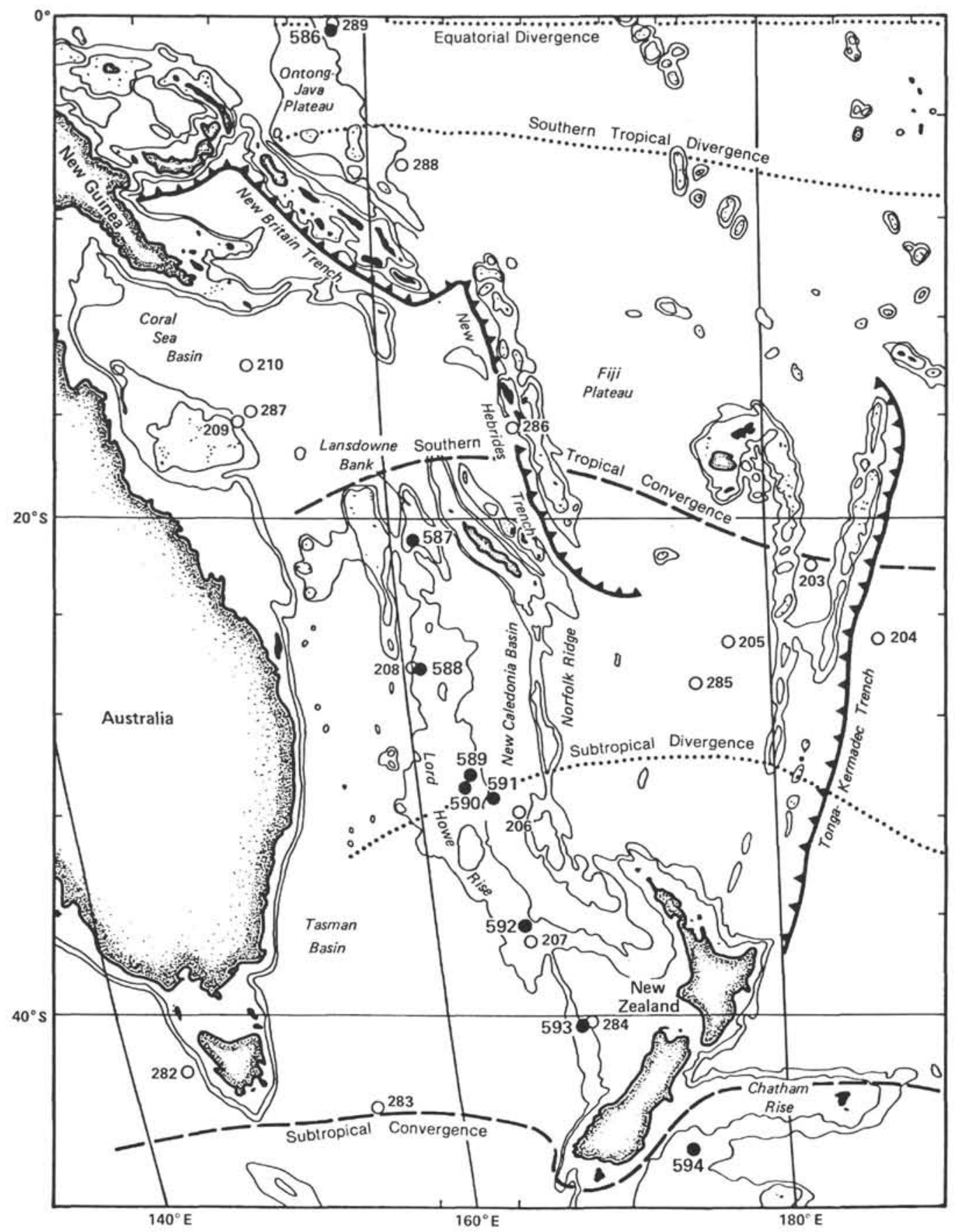

Figure 1. Sites occupied during Leg 90 (solid circles) and other legs (open circles) in the southwest Pacific. Fish otoliths were encountered only at Sites 587 and 594.

in Hole $373 \mathrm{~A}$ in the Tyrrhenian Basin at the exceptional present water depth of $3517 \mathrm{~m}$-later subsidence is a possible explanation-and in Holes 376 (present water depth $1900 \mathrm{~m}$ ) and 378 (present water depth $1835 \mathrm{~m}$ ).

\section{SYSTEMATIC DESCRIPTION}

Family GONOSTOMIDAE Gill, 1892

(Lightfish or Deepsea Bristlemouths)

Genus BONAPARTIA Goode and Bean, 1896

Bonapartia sp.

(Plate 1, Figs. 15, 16)

One eroded specimen from Sample 587-2,CC belongs to this genus. The shape of the sulcus is characteristic for the family. The mid- dle part of the cauda is the widest and deepest part. The ostium is only vaguely visible because of erosion. The shape of the outline is very similar to that of $B$. pedalotia, apart from a clearly concave part directly behind the antirostrum. It is not clear whether this is an erosional phenomenon or a primary structure. The otolith length/height ratio agrees well with that of $B$. pedalotia (Kotthaus, 1972a, fig. 27).

\section{Genus VALENCIENNELUS Jordan and Evermann in Goode and Bean, 1896}

Valenciennellus tripunctulatus (Esmark, 1871)

(Plate 1, Figs. 9, 10, 23, 24)

Two sagittae found in Samples 587-1,CC and 587-2,CC are assigned to this species. Both specimens are rounded and the height is greater than the length. Rostrum and antirostrum are nearly of equal 
Table 1. Distribution and preservation of fish otoliths in samples from Holes 587 and 594.

\begin{tabular}{|c|c|c|c|c|c|c|c|c|c|c|c|c|c|}
\hline Sample & 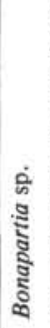 & 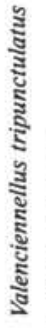 & 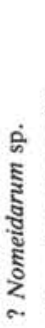 & 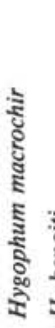 & : & 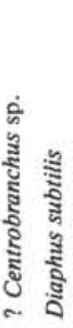 & 离 & 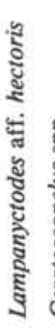 & 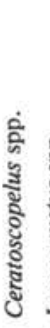 & 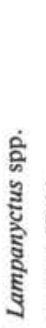 & 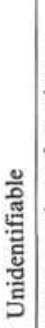 & 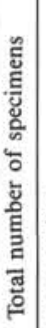 & 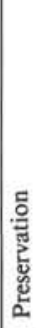 \\
\hline $587-1, \mathrm{CC}$ & & 1 & & & 1 & 1 & & & 1 & 1 & 1 & 6 & M \\
\hline $587-2, C C$ & 1 & 1 & 1 & 1 & & 1 & & & 4 & & 2 & 11 & M \\
\hline $587-3, \mathrm{CC}$ & & & & & & 2 & 5 & & 7 & 1 & 29 & 44 & P \\
\hline $594-3, C C$ & & & & & & & & 1 & & & & 1 & G \\
\hline
\end{tabular}

Note: For preservation, $\mathbf{G}=$ good, $\mathrm{M}=$ moderate, $\mathrm{P}=$ poor.

size. A small excisura is present in both specimens. The ventral rim of the sulcus is prominent and bent downward along the ostium. The ostium is relatively small compared with the elongated cauda. The outer face is smooth, but may be affected by corrosion. Both sagittae are very similar to the specimen of Valenciennellus tripunctulatus (Esmark, 1871) figured in Kotthaus (1972a, fig. 30). Other illustrations of this species can be found in Kotthaus (1967, text-fig. 31) and Weitzman (1974, text-fig. 42D). The species is widespread and is caught in all oceans (Kotthaus, 1972a, p. 8).

\section{Family MYCTOPHIDAE Gill, 1892 (Lanternfishes) \\ Genus HYGOPHUM Tåning, 1932 \\ Hygophum macrochir (Günther, 1864)}

(Plate 1, Figs. 5, 6)

One specimen in Sample 587-2,CC can be assigned to this species. Length and height are more or less equal, the antirostrum is a little less prominent than the rostrum and is separated from the latter by a distinct excisura. The postventral part is steep and straight. The ostium is larger than the cauda, the base of which does not reach the same level as the base of the ostium. The dorsal margin is characteristic for the species. It shows some undulation and has a rounded predorsal angle and a more prominent postdorsal angle; the parts between the angles and between postdorsal angle and caudal end are nearly straight (see Schwarzhans, 1980, text-fig. 104; Hecht and Hecht, 1981, textfig. 49).

Hygophum atratum (Garman, 1891) shows many similarities with $H$. macrochir. It differs from the latter species by having more prominent dorsal angles lying farther apart, less ornamentation along its margins, and more oblique otoliths which are rather pointed in the middle of the ventral rim (otolith in Gaemers collection, donated by the late J. E. Fitch; see also Weiler, 1971, plate 1, fig. 23, although this specimen seems to be more strongly ornamented). The specimen illustrated as $H$. atratum by Schwarzhans, 1980, however, differs in many respects; it is therefore doubtful if it belongs to the same species, unless the otoliths show a strong allometrical growth.

\section{Hygophum benoiti (Cocco, 1838)}

$$
\text { (Plate 1, Figs. 3, 4) }
$$

A left sagitta assigned to this species was found in Sample 587$1, \mathrm{CC}$. The height is slightly greater than the length. It has a distinct rostrum and a smaller antirostrum, separated by an excisura. The antirostrum is somewhat blunt (probably caused by erosion), leading to an angle on the dorsal margin of the sagitta, which shows some undulation related to two grooves on the outer face. The inner face is worn, but ostium and cauda seem to be of about equal length with the bases in line. The regularly rounded dorsal rim is characteristic for $H$. benoiti (see Schwarzhans, 1980, text-fig. 105; Hecht and Hecht, 1981, text-fig. 48; Nolf and Steurbaut, 1983, plate 2, figs. 28-33).

\section{Genus CENTROBRANCHUS Fowler, 1904 \\ ?Centrobranchus sp. \\ (not figured)}

Two small otoliths from Sample 587-3,CC may belong to the genus Centrobranchus. Their length is greater than their height. The rostrum is small and an antirostrum is not developed. Both specimens have a distinct postdorsal angle. The ostium is larger than the cauda in the better-preserved specimen. At present they can be best compared with Centrobranchus nigroocellatus in Kotthaus (1972a, text-fig. 64).

\section{Genus DIAPHUS Eigenmann, 1891 \\ Diaphus subtilis Nafpaktitis, 1968 \\ (Plate 1, Figs. 21, 22, 25, 26)}

Two otoliths belonging to the genus Diaphus were recovered at Site 587. In Sample 587-1,CC (Plate 1, Figs. 25, 26) a small left sagitta with a distinct rostrum can be assigned to Diaphus subtilis (see Kotthaus, 1972a, text-fig. 73), but differs in having no antirostrum and an excisura that is reduced to a groove on the outer face. As the dentation on the ventral rim and the outer face is rather smooth this may represent a corroded specimen with details lost. The ostium is slightly larger than the cauda and a faint area is present on the dorsal part. The left sagitta found in Sample 587-2,CC (Plate 1, Figs. 21, 22) is slightly larger, having a somewhat blunt rostrum and a small excisura and antirostrum. Two incisions followed by grooves on both faces are developed on the dorsal rim. On the ventral rim a small projection can be noted. Otherwise the sagitta looks corroded, with an obscured sulcus. The asymmetrical, triangular outline is typical for $D$. subtilis (several otoliths available for comparison in Gaemers collection, donation J. Craddock, Woods Hole).

\section{?Diaphus sp. \\ (not figured)}

Five badly worn otoliths from Sample 587-3, CC seem to belong to the genus Diaphus. One worn otolith from Sample 587-3,CC still shows some faint radial grooves on the outer face.

\section{Genus LAMPANYCTODES Fraser-Brunner, 1949 \\ Lampanyctodes aff. hectoris (Günther, 1876)}

(Plate 1, Figs. 1, 2)

The single right sagitta from Sample $594-3, \mathrm{CC}$ is somewhat eroded. The ventral rim is undulated, the incisions resulting in grooves on the outer face. It has a prominent antirostrum, whereas the rostrum is less distinct because of erosion. Originally antirostrum and rostrum were probably equally prominent. The ostium is large and about one and a half times the length of the cauda. A crista superior is well developed and separates the sulcus from the area. The otolith very much resembles that figured in Karrer, 1973 as $L$. hectoris in the gradually rising dorsal rim from antirostrum to the rounded postdorsal angle. Other characteristics which are very similar are antirostrum, excisura, ventral furrow, and sulcus (see the specimens of $L$. mimiensis in Schwarzhans, 1980). The ostial colliculum in the specimen figured by Karrer must erroneously have been confined to the posterior part of the ostium as she also incorrectly did in the otoliths of Diaphus dumerili and $D$. taaningi. The dentation, which is clearly visible in Karrer's drawing, was probably smoothed in the fossil specimen by erosion. This otolith differs from Karrer's illustration in having a stronger ornamentation on the outer face and a more rounded posterior rim. The latter may be the result of a somewhat stronger erosion along the ventral part of this rim.

\section{Genus CERATOSCOPELUS Günther, 1864 \\ Ceratoscopelus sp. \\ (Plate 1, Figs. 11-14, 17-20, and 29-30)}

Several otoliths from Hole 587 belong to the genus Ceratoscopelus. One right sagitta from Sample 587-1,CC (Plate 1, Figs. 29, 30) is tentatively assigned to the genus Ceratoscopelus, as it is elongated and rounded, has a small excisura, a distinctive rostrum, and a very indistinct antirostrum. Several specimens from Sample 587-2,CC (Plate 1, 
Figs. 13, 14, and 17-20) are more or less corroded, but still show a distinct rostrum, a less distinct antirostrum, and the general outline of otoliths of the genus Ceratoscopelus. If the inner face is less corroded the ostium is definitely larger than the cauda. One specimen (Plate 1, Figs. 19, 20) shows some similarities with Ceratoscopelus madarensis (Kotthaus, 1972a, text-fig. 92) in having a rather angular outline, which is obvious in the postdorsal angle and the posterior end. Three specimens (Plate 1, Figs. 13-14, 17-18, and 29-30) seem to represent Ceratoscopelus warmingi (Kotthaus, 1972a, text-fig. 91) as they have a more rounded outline. Seven badly worn otoliths from Sample 587$3, \mathrm{CC}$ are also placed into this genus, as the outline seems to fit the general description of the genus. A large, badly worn otolith from Sample $587-2, \mathrm{CC}$ probably also belongs to this genus.

\section{Genus LAMPANYCTUS Bonaparte, 1840}

Lampanyctus sp.

(Plate 1, Figs. 7, 8)

One left sagitta from Sample $587-1, \mathrm{CC}$ is assigned to the genus Lampanyctus because the rostrum is short, the excisura is small, and the antirostrum not very prominent. The ventral rim and the outer face are smooth. The specimen has a distinct postdorsal angle, and the ostium is about twice the size of the cauda. The sagitta is similar to some Lampanyctus species figured in Nolf and Steurbaut (1983, plate 2, figs. 34-41 and 46-51), one of which comes from the Tortonian stratotype in Italy. Another otolith found in Sample 587-3,CC is badly worn and is only tentatively assigned to this genus.

Family NOMEIDAE Günther, 1880

?Nomeidarum sp.

(Plate 1, Figs. 27, 28)

A single, right, probably juvenile sagitta from Sample 587-2,CC having clear perciform characters belongs to the suborder Stromateoidei. It is somewhat elongated, with a prominent rostrum and a small antirostrum which is separated from the rostrum by a distinct excisura. The sulcus is wide and long, and slightly bent downward at the posterior end. The ventral part of the outer face shows distinct radiating grooves.

Otoliths of many species of this suborder are still unknown and no Recent material is available from the Tetragonuridae and Pampidae. The outline of the otolith shows some resemblances to otoliths of the Stromateidae family (see Schmidt, 1968, plate 10, figs. 142-144, and plate 22). The present otolith does not belong to the Centrolophidae family, which possesses otoliths with a narrow sulcus. Butler (1979) illustrates otoliths of four Cubiceps species belonging to the Nomeidae family. The fossil otolith resembles $C$. baxteri the most in general outline, rostrum, antirostrum, and excisura. It resembles $C$. pauciradiatus the most in the shape of the sulcus and ornamentation. It may belong to a genus of the Nomeidae of which the otoliths are still unknown. Judging by the otoliths of the four Cubiceps species illustrated by Butler (1979), it seems indeed inevitable that these species belong to three different genera: the differences in the shapes of the outline and sulcus are too large for inclusion in only one genus.

\section{Unidentifiable otoliths \\ (Plate 2, Figs. 1-5)}

In Samples 587-1,CC and 587-2,CC three broken pieces of otoliths were recovered but could not be identified. In Sample 587-3,CC, 29 otoliths could not be identified because they are heavily worn, with the inner face more or less dissolved. Most probably they belong to the lanternfish family (Myctophidae). Some of these are split along the median axis, showing excellent growth patterns discussed below.

Heavy corrosion and solution signs are always noted on the inner face, where deep depressions, including the central core, are visible. The marked differences in the fine structure within and outside the sulcus probably caused the selective corrosion of the inner face of deep sea fish otoliths, as discussed by Martini (1974) ${ }^{3}$. The present

\footnotetext{
${ }^{3}$ Magnification for figs. $\mathrm{tb}$ and $1 \mathrm{c}$ in Martini, 1974, should read $\times 450$ rather than
}

material supports this assumption, as only the inner faces are dissolved and the outer faces are commonly better preserved.

\section{FINE STRUCTURE AND GROWTH LAYERS}

Growth layers in fish otoliths are commonly considered as seasonal accretions of calcium carbonate in the form of aragonite prisms and an organic matrix consisting of protein (Degens et al., 1969). The larger and transparent layers are built during spring and summer. The smaller and darker layers represent slower accretion during late summer and autumn (Weiler, 1958). They are termed "summer" and "winter" layers, although pluvial and dry periods or changes in temperature may also result in different growth layers. Pannella (1971) demonstrated that growth takes place by daily increments, and recurrent patterns show a fortnightly and monthly periodicity. Also spawning rings were microscopically distinguishable from "winter"-rings.

Several otoliths from Sample 587-3,CC are split along their median axis and are somewhat etched, revealing detailed growth layers. A typical specimen, which unfortunately cannot be assigned to any family, is figured on Plate 2 using scanning electron microscope (SEM) techniques. The embryonal core is clearly visible (Plate 2, Fig. 1) and the aragonite fibers show only faint layering (Plate 2, Fig. 2). The more prominent rings succeeding each other in declining thickness may indicate an age of 4.5 yr. for the present specimen. Within the supposed seasonal sections a series of additional layers is visible in the first two cycles; they consist of about 15 layers in the second cycle. In the third and fourth cycle the total thickness is smaller than in the first and second cycles; this may be related to sexual maturity (Pannella, 1971). With this age the accretion of aragonite slows down, resulting in slower growth of the otoliths. Within the third and fourth cycle several distinct accretion layers of somewhat spongy aragonite fibers can be observed (Plate 2, Figs. 3-5). At present these cannot be related to any seasonal fluctuation in the life cycles of deep sea fishes, although one possibility, besides those discussed by Pannella (1979), may also be dependence on the life cycle of copepods. Additional investigations of better-preserved material are necessary to evaluate the nature of growth layers in deep sea fish otoliths.

\section{DISCUSSION}

The Quaternary otolith association of Hole 587 on Lord Howe Rise is clearly dominated $(86.5 \%)$ by otoliths of the Lanternfish family (Myctophidae); $10 \%$ are from Deepsea Bristlemouths (Gonostomidae), and only $3.5 \%$ can be attributed to the ?Stromatoidei, if one leaves aside the unidentifiable otoliths.

The Myctophidae are mesopelagic fishes forming gigantic swarms at between 200 and $1000 \mathrm{~m}$. On dark nights they rise close to the surface following copepods, their favorite food (Schwarzhans, 1980). Myctophidae otoliths also dominate Recent otolith assemblages in oceanic sediments below approximately $150 \mathrm{~m}$ (Wigley and Stinton, 1973). The Deepsea Bristlemouths commonly inhabit the seas offshore New Zealand below $1000 \mathrm{~m}$ 
(Ayling and Cox, 1982), whereas most Stromateoids are epi- and mesopelagic fishes in all oceans.

The otolith association of Hole 587 is very similar to the assemblages of Holes 242 and 246 in the Indian Ocean (Martini, 1974), where the Myctophidae also clearly dominate. The present water depths of these localities are all below $1000 \mathrm{~m}$. In depths not exceeding $407 \mathrm{~m}$ around southern Norway, Gaemers (1978) reported the importance of Gadidae together with Myctophidae in the deeper assemblages, quite different in this aspect from true deep sea occurrences.

In Hole 587 pteropod shells are found in all corecatcher samples $(587-1, \mathrm{CC}-587-4, \mathrm{CC})$ investigated for the present study. As pteropod shells, like the otoliths, are built of aragonite, their dissolution patterns in the world oceans are closely related. Berger (1978) reported the critical depth for pteropod shell preservation in the area of Site 587 as between 1100 and $1300 \mathrm{~m}$, in accordance with the present water depth at Site 587, in which fish otoliths are rather common. At Site 594 only one well-preserved otolith was found in Sample 594-3,CC. Core-catcher samples from Hole 594B were checked in detail from 594B-1,CC to 594B-5,CC, but no further otoliths were found. Pteropod shells are missing, in accordance with data given in Berger (1978, fig. 1). The sieved fraction (greater than $63 \mu \mathrm{m}$ ) contains abundant planktonic foraminifers and, in varying frequency, benthic foraminifers, chinoid spines, sponge spicules, ostracodes, and very rare Chlamys in Sample 594B-3,CC. Some of this material may be redeposited from higher levels, as discussed in the Site 594 site chapter; the single otolith of the genus Lampanyctodes may also be erratic.

Fish otoliths from the New Zealand Tertiary are described in several papers by Frost $(1924,1928,1933)$, Stinton (1957), Schwarzhans (1980), and Grenfell (1984). Schwarzhans revised the earlier literature and he also figured otoliths from Recent species for comparison. The Myctophidae played an important role in the Tertiary fish assemblages of New Zealand, as they do today. From the myctophid otoliths from Holes 587 and 594 only the genera Centrobranchus and Ceratoscopelus seem not to be represented in the Tertiary of New Zealand. Furthermore, representatives of the genus Valenciennellus (Family Gonostomidae) may be restricted to the Quaternary. For occurrences of Recent species compared with the otoliths found in Holes 587 and 594, the detailed papers by Kawaguchi et al. (1972), Kawaguchi and Shimizu (1978), and Kotthaus (1972a, b) should be consulted.

\section{ACKNOWLEDGMENTS}

Thanks are due to the Deutsche Forschungsgemeinschaft (BonnBad Godesberg) for supporting the present study. B. Kahl (GeologischPaläontologisches Institut der Universität, Frankfurt am Main) made the excellent photographs of the otoliths (Plate 1). SEM pictures (Plate 2) were taken by J. Tochtenhagen with a Stereoscan Mark 2, which was provided to the Geologisch-Paläontologisches Institut der Universität, Frankfurt am Main, by the VW-Stiftung. Our thanks also go to Dr. W. Schwarzhans (Berlin) for valuable discussions and for reviewing this paper.

\section{REFERENCES}

Ayling, T., and Cox, G. J., 1982. Collins Guide to the Sea Fishes of New Zealand: Auckland (Collins Publ. Ltd.).
Beckmann, J. P., 1976. Shallow-water foraminifers and associated microfossils from Sites 315, 316, and 318, DSDP Leg 33. In Schlanger, S. O., Jackson, E. D., et al., Init. Repts. DSDP, 33: Washington (U.S. Govt. Printing Office), 467-489.

Berger, W. H., 1978. Deep-sea carbonate: pteropod distribution and the aragonite compensation depth. Deep-Sea Res., 25:447-452.

Bizon, G., Cita, M. B., Müller, C. and Wright, R., 1978. DSDP Leg 42A biostratigraphic range charts. In Hsü. K. J., Montadert, L., et al., Init. Repts. DSDP, 42, Pt. 1: Washington (U.S. Govt. Printing Office), $1095-1138$.

Butler, J. L., 1979. The nomeid genus Cubiceps (Pisces) with a description of a new species. Bull. Mar. Sci., 29(2):226-241.

Degens, E. T., Deuser, W. G., and Haedrich, R. L., 1969. Molecular structure and composition of fish otoliths. Mar. Biol., 2(2):105-113.

Frost, E. A., 1924. Otoliths of fishes from the Tertiary formations of New Zealand. Trans. Proc. N. Z. Inst., 55:605-614.

1928. Otoliths of fishes from the Tertiary formations of New Zealand and Balcombe Bay, Victoria. Trans. Proc. N. Z. Inst., 59:91-97.

1933. Otoliths of fishes from the Tertiary formations of New Zealand. Trans. Proc. N. Z. Inst., 63:133-142.

Gaemers, P. A. M., 1978. Late Quaternary and Recent otoliths from the seas around southern Norway. Meded. Werkgr. Tert. Kwart. Geol., 15:101-117.

Grenfell, H. R., 1984. Early Miocene teleost otoliths from Parengarenga Harbour, New Zealand. N. Z. J. Geol. Geophys., 27:51-96.

Hecht, T., and Hecht, A., 1981. A descriptive systematic study of the otoliths of the neopterygean marine fishes of South Africa. Part IV: Siluriformes and Myctophiformes. Trans. R. Soc. S. Afr., 44(3): 401-440.

Karrer, C., 1973. Ueber Fische aus dem Südostatlantik. Mitt. Zool. Mus. Berlin, 49(1):191-257.

Kawaguchi, K., Ikeda, H., Tamura, M., and Ueyanagi, S., 1972. Geographical distribution of surface-migrating myctophid fishes (genus Myctophum) in the tropical and subtropical Pacific and Indian Oceans. Bull. Far Seas Fish Res. Lab., 6:23-37.

Kawaguchi, K., and Shimizu, H., 1978. Taxonomy and distribution of the lanternfishes, genus Diaphus (pisces, Myctophidae) in the western Pacific, eastern Indian Oceans and the southeast Asian Seas. Bull. Ocean Res. Inst. Univ. Tokyo, 10:1-145.

Kotthaus, A., 1967. Fische des Indischen Ozeans. Ergebnisse der ichthyologischen Untersuchungen während der Expedition des Forschungsschiffes "Meteor" in den Indischen Ozean, Oktober 1964 bis Mai 1965. "Meteor" Forsch., DI, pp. 1-84.

1972a. Die meso- und bathypelagischen Fische der "Meteor"-Rossbreiten-Expedition 1970 (2. und 3. Fahrtabschnitt). "Meteor" Forsch., D11, pp. 1-28.

, 1972b. Fische des Indischen Ozeans. Ergebnisse der ichthyologischen Untersuchungen während der Expedition des Forschungsschiffes "Meteor" in den Indischen Ozean. Oktober 1964 bis Mai 1965. A. Systematischer Teil, IX. Iniomi (Nachtrag: Fam. Myctophidae). "Meteor"-Forsch., D12, pp. 12-35.

Martini, E., 1974. Quaternary fish otoliths from Sites 242 and 246Leg 25, Deep Sea Drilling Project. In Simpson, E. S. W., Schlich, R., et al., Init. Repts. DSDP, 25: Washington (U.S. Govt. Printing Office), 647-655.

Nolf, D., and Steurbaut, E., 1983. Révision des otolithes de téléostéens du Tortonien stratotypique et de Montegibbo (Miocène Supérieur d'Italie septentrionale). Meded. Werkgr. Tert. Kwart. Geol., 20(4):143-197.

Pannella, G., 1971. Fish otoliths: daily growth layer and periodical patterns. Science, 173:1124-1127.

Schmidt, W., 1968. Vergleichend morphologische Studie über die Otolithen mariner Knochenfische. Arch. Fischereiwiss., 19,1:1-96.

Schwarzhans, W., 1980. Die tertiäre Teleosteer-Fauna Neuseelands, rekonstruiert anhand von Otolithen. Berl. Geowissensch. Abh., A 26:1-211.

Steurbaut, E., 1982. Les otolithes de téléostéens du gisement de Peyrère à Peyrehorade (couches de passage de l'Oligocène au Miocène d'Aquitaine méridionale, France). Meded. Werkgr. Tert. Kwart. Geol., 19(2):35-57. 


\section{E. MARTINI, P. A. M. GAEMERS}

Stinton, F., 1957. Teleostean otoliths from the Tertiary of New Zealand. Trans. R. Soc. N.Z., 84:513-517.

Weiler, W., 1958. Fischreste, insbesondere Otolithen. In Freund, H. (Ed.), Handbuch der Mikroskopie in der Technik (Vol. 2) (3): Frankfurt am Main (Umschau Verlag), pp. 265-280.

1971. Fisch-Otolithen aus dem Jungtertiär Süd-Siziliens, Senckenb. Leth. 52(1):5-37.
Weitzman, S. H., 1974. Osteology and evolutionary relationships of the Sternoptychidae, with a new classification of Stomatoid otoliths. Bull. Am. Mus. Nat. Hist., 153(3):331-478.

Wigley, R. L., and Stinton, F. C., 1973. Distribution of macroscopic remains of Recent animals from marine sediments off Massachusetts. Fish. Bull. (U.S.), 71(1):1-40.

Date of Initial Receipt: 4 June 1984

Date of Acceptance: 26 October 1984 

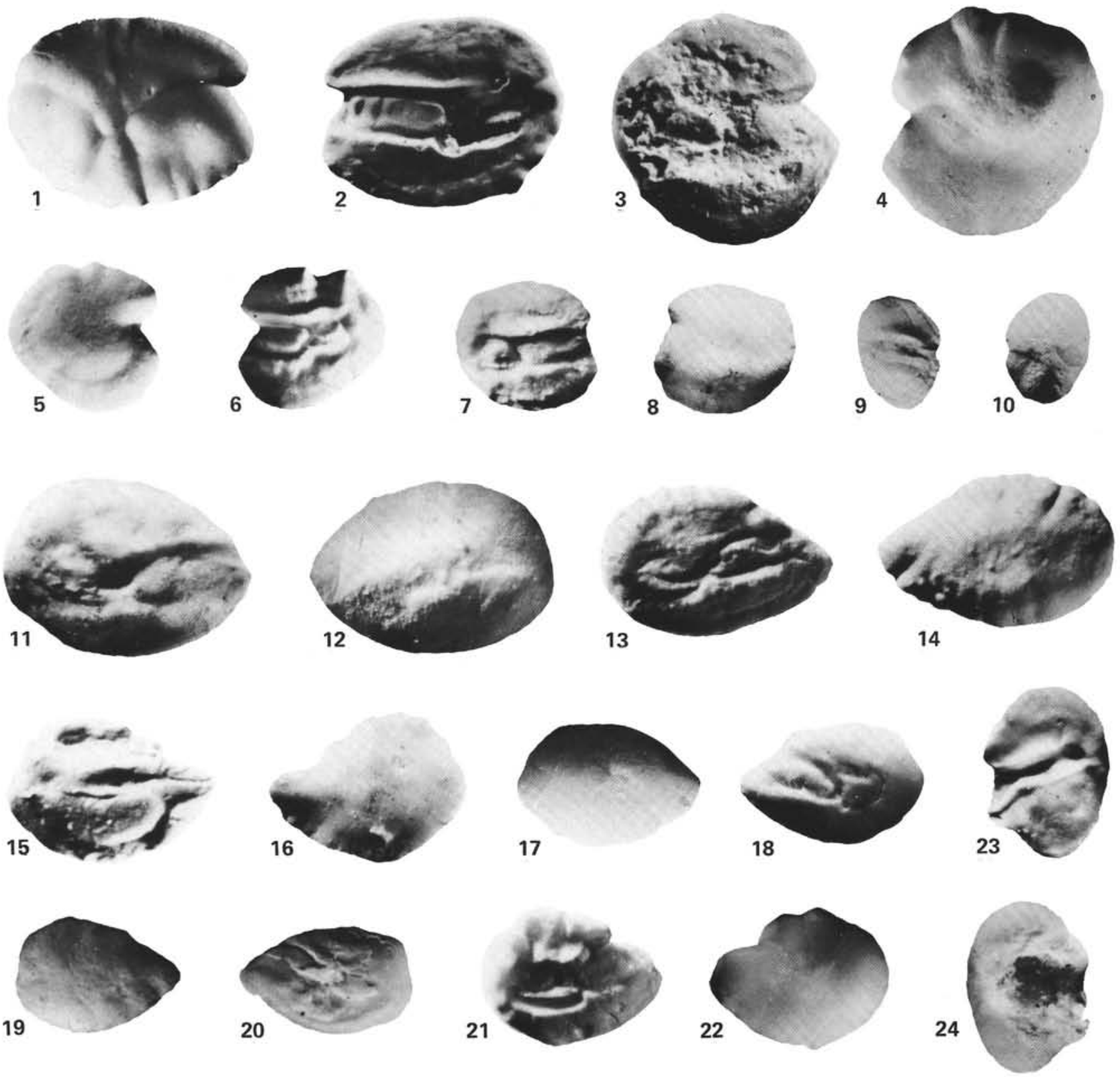

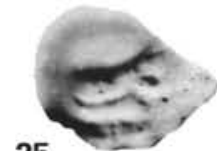

25

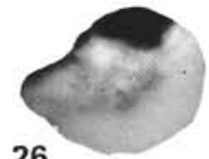

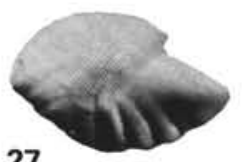

27

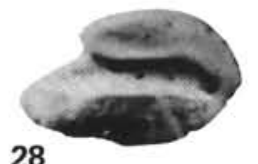

28

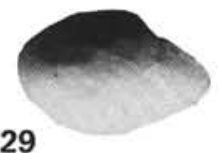

29

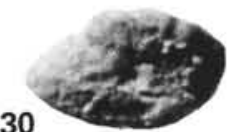

Plate 1. (All specimens approximately $\times 20) \quad 1,2$. Lampanyctodes aff. hectoris, right sagitta, Sample $594-3, C C$, (1) outer face; (2) inner face. 3, 4. Hygophum benoiti, left sagitta, Sample 587-1,CC, (3) inner face; (4) outer face. 5, 6. Hygophum macrochir, right sagitta, Sample 587-2,CC, (5) inner face; (6) outer face. 7, 8. Lampanyctus sp., left sagitta, Sample 587-1,CC, (7) inner face; (8) outer face. 9, 10. Valenciennellus tripunctulatus, left sagitta, Sample 587-2,CC, (9) inner face; (10) outer face. 11, 12. Ceratoscopelus sp., left sagitta, Sample 587-2,CC, (11) inner face; (12) outer face. 13, 14. Ceratoscopelus sp. cf. C. warmingi, left sagitta, Sample 587-2,CC, (13) inner face; (14) outer face. 15, 16. Bonapartia sp., left sagitta, Sample $587-2, C C$, (15) inner face; (16) outer face. 17, 18. Ceratoscopelus sp. cf. C. warmingi, right sagitta, Sample 587-2,CC, (17) outer face; (18) inner face. 19, 20. Ceratoscopelus sp. cf. C. maderensis, right sagitta, Sample 587-2,CC, (19) outer face; (20) inner face. 21, 22. Diaphus subtilis, left sagitta, Sample 587-2,CC, (21) inner face; (22) outer face. 23, 24. Valenciennellus tripunctulatus, right sagitta, Sample 587-1,CC, (23) inner face; (24) outer face. 25, 26. Diaphus subtilis, left sagitta, Sample 587-1,CC, (25) inner face; (26) outer face. 27, 28. ?Nomeidarum sp., right sagitta, Sample 587-2,CC, (27) outer face; (28) inner face. 29, 30. Ceratoscopelus sp. cf. C. warmingi, left sagitta, Sample $587-1, \mathrm{CC},(29)$ inner face; (30) outer face. 

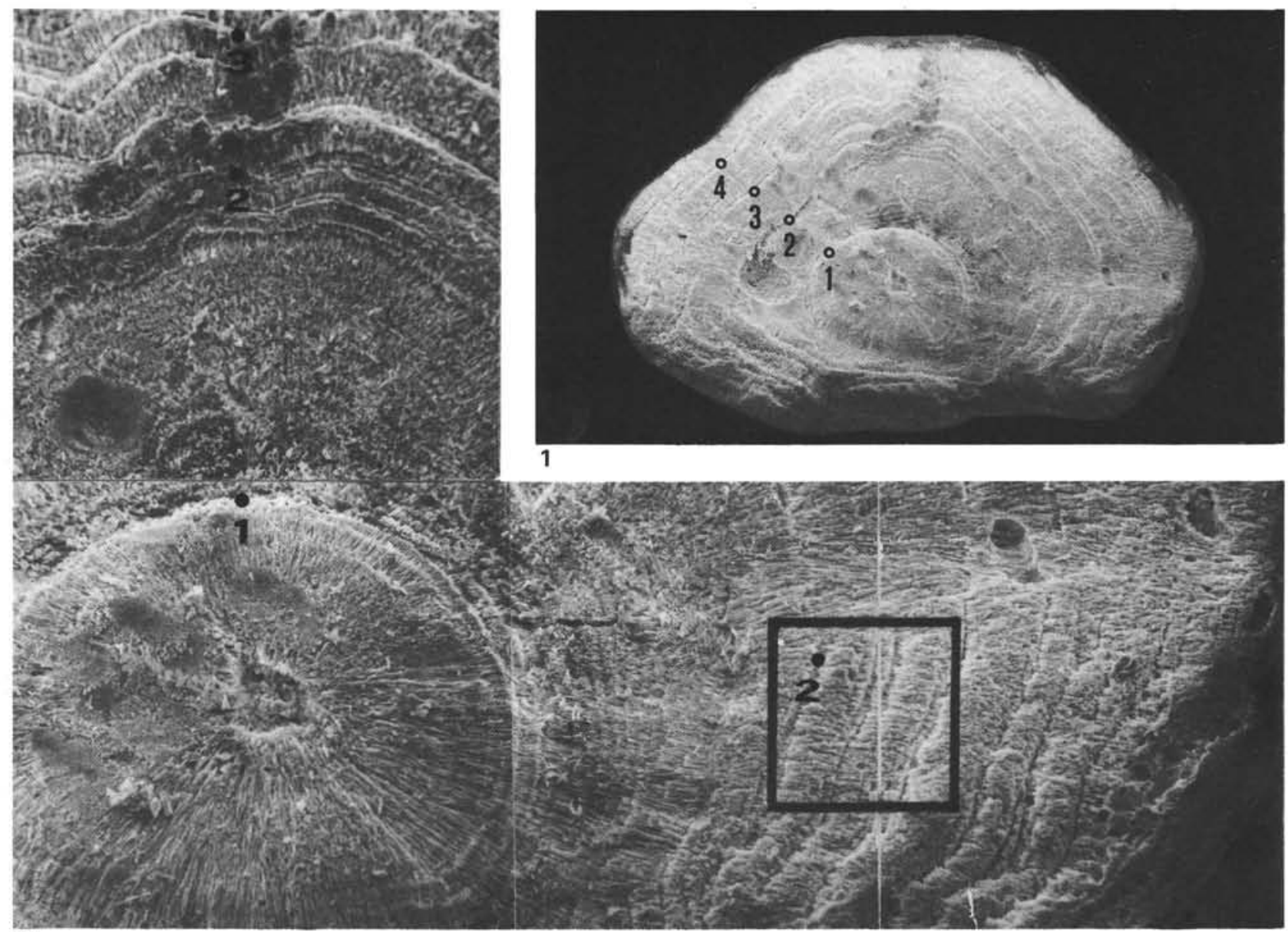

2

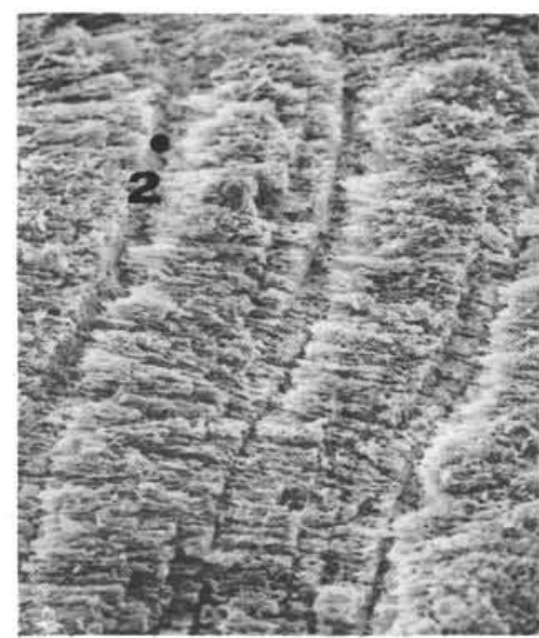

3

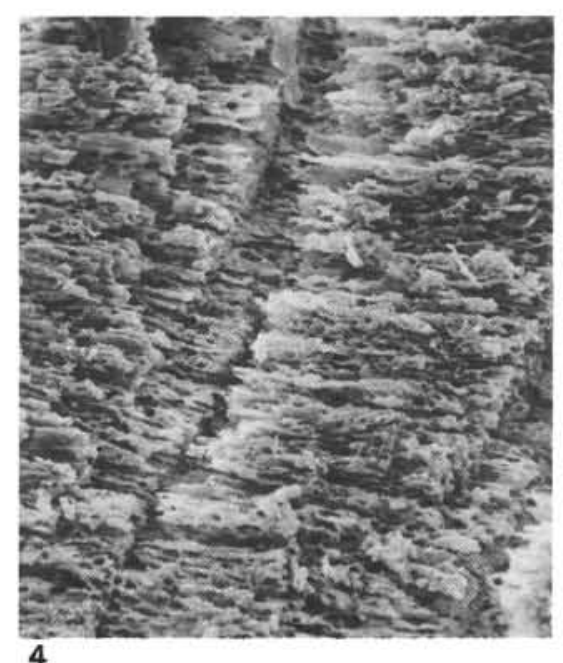

4

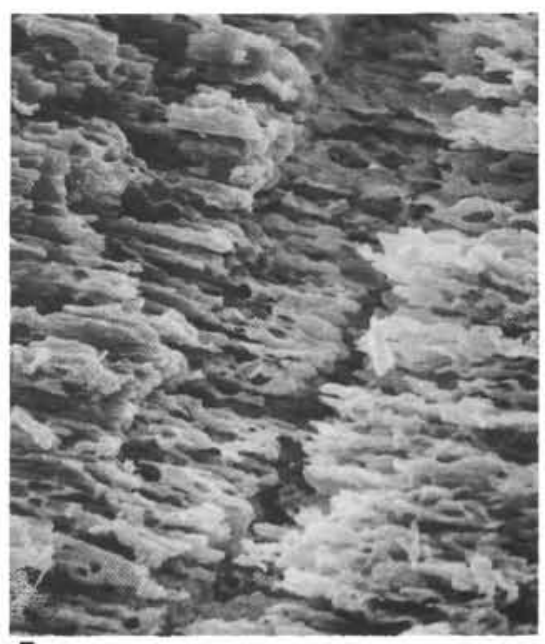

5

Plate 2. SEM pictures of unidentified otolith, corroded inner face showing growth layers, from Sample 587-3,CC. 1. Overall view, $\times 42$. 2. Enlarged section of Figure 1, $\times 145$. 3-5. Details of growth layers in the right part of Fig. 2 (square), (3) $\times 365 ;(4) \times 730,(5) \times 1460$. 